\title{
Correction to: Influence of physical training on erythrocyte concentrations of iron, phosphorus and magnesium
}

Marcos Maynar Mariño ${ }^{1}$, Francisco Javier Grijota ${ }^{2}$, Ignacio Bartolomé ${ }^{1}$, Jesús Siquier-Coll1, Victor Toro Román ${ }^{1}$ and Diego Muñoz ${ }^{1 *}$

\section{Correction to: J Int Soc Sports Nutr 17, 8 (2020) https://doi.org/10.1186/s12970-020-0339-y}

The original article [1] contains an error in Table 4 whereby values are incorrectly displayed due to a misplaced separator. The correct version of Table 4 can be viewed ahead in this Correction article.

\section{Author details \\ ${ }^{1}$ Sport Sciences Faculty, University of Extremadura, Avenida de la Universidad $s / n, 10003$ Cáceres, Spain. ${ }^{2}$ Education Faculty, University of Extremadura, Avenida de la Universidad s/n, 10003 Cáceres, Spain.}

Published online: 30 June 2020

\section{Reference}

1. Maynar Mariño M, et al. Influence of physical training on erythrocyte concentrations of iron, phosphorus and magnesium. J Int Soc Sports Nutr. 2020;17:8 https://doi.org/10.1186/s12970-020-0339-y.

The original article can be found online at https://doi.org/10.1186/s12970020-0339-y.

* Correspondence: diegomun@unex.es

${ }^{1}$ Sport Sciences Faculty, University of Extremadura, Avenida de la Universidad s/n, 10003 Cáceres, Spain

Full list of author information is available at the end of the article

(c) The Author(s). 2020 Open Access This article is licensed under a Creative Commons Attribution 4.0 International License, which permits use, sharing, adaptation, distribution and reproduction in any medium or format, as long as you give appropriate credit to the original author(s) and the source, provide a link to the Creative Commons licence, and indicate if changes were made. The images or other third party material in this article are included in the article's Creative Commons licence, unless indicated otherwise in a credit line to the material. If material is not included in the article's Creative Commons licence and your intended use is not permitted by statutory regulation or exceeds the permitted use, you will need to obtain permission directly from the copyright holder. To view a copy of this licence, visit http://creativecommons.org/licenses/by/4.0/. The Creative Commons Public Domain Dedication waiver (http://creativecommons.org/publicdomain/zero/1.0/) applies to the data made available in this article, unless otherwise stated in a credit line to the data. 
Table 4 Concentrations of Fe, Mg and P in CG and sportsmen classified by the level of training

\begin{tabular}{llll}
\hline & $\begin{array}{l}\text { CG } \\
(n=30)\end{array}$ & $\begin{array}{l}\text { MTG } \\
(n=24)\end{array}$ & $\begin{array}{l}\text { HTG } \\
(n=22)\end{array}$ \\
\hline Fe $(\mathrm{mg} / \mathrm{gHb})$ & $9.07 \pm 1.52$ & $6.59 \pm 2.11^{+++}$ & $5.23 \pm 0.79+++^{*}$ \\
$\mathbf{M g}(\mu \mathrm{g} / \mathrm{gHb})$ & $386.9 \pm 68.8$ & $273.5 \pm 92.5^{+++}$ & $235.2 \pm 40.9++\dagger$ \\
$\mathbf{P}(\mathrm{mg} / \mathrm{gHb})$ & $5.46 \pm 0.94$ & $4.36 \pm 1.21^{+++}$ & $4.05 \pm 0.44++\dagger$ \\
\hline
\end{tabular}

Anova and Bonferroni tests

t Differences between the HTG and CG ( $t p<0.05 ;+t p<0.01 ;+t+p<0.001)$

+ Differences between the MTG and CG $(+p<0.05 ;++p<0.01 ;+++p<0.001)$

${ }^{*}$ Differences between the MTG and HTG $\left({ }^{*} p<0.05 ;{ }^{* *} p<0.01 ;{ }^{* * *} p<0.001\right)$ 